\title{
Pyrolysis Bio-oil and Bio-char Production from Firewood Tree Species for Energy and Carbon Storage in Rural Wooden Houses of Southern Ethiopia
}

\author{
Miftah F. Kedir
}

\section{Contents}

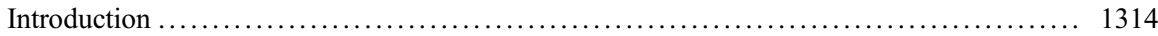

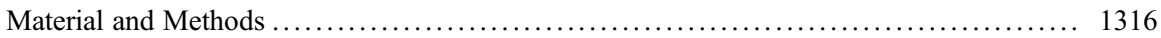

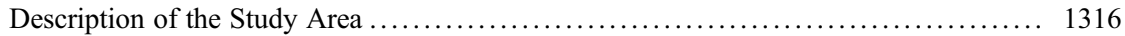

Methods of Data Collection and Analyses .................................. 1317

Results ........................................................... 1321

Bio-oil and Bio-char Yield of Different Woody Biomasses Species ................ 1321

Calorific Value and Moisture Content of Bio-oil and Bio-char in Comparison

with the Parent Firewood ............................................. 1321

Fixed Carbon, Volatile Matter, and Moisture Content of Different Tree Species Bio-

chars ............................................................. 1323

The Potential of Pyrolysis Oil and Bio-char in Reducing Firewood End Use

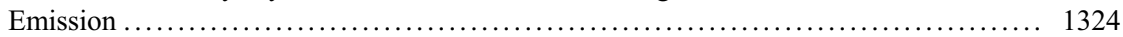

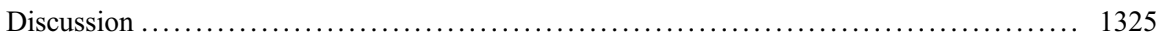

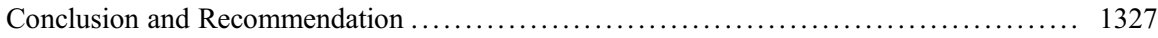

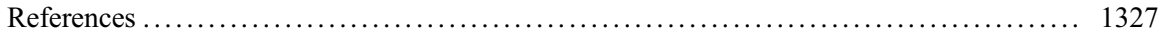

\section{Abstract}

The need for emission reduction for climate management had triggered the application of pyrolysis technology on firewood that yield bio-oil, bio-char, and syngas. The purpose of present study was to select the best bio-oil and bio-char producing plants from 17 firewood tree species and to quantify the amount of carbon storage. A dried and $1 \mathrm{~mm}$ sieved sample of $150 \mathrm{~g}$ biomass of each species

This chapter was previously published non-open access with exclusive rights reserved by the Publisher. It has been changed retrospectively to open access under a CC BY 4.0 license and the copyright holder is "The Author(s)". For further details, please see the license information at the end of the chapter.

M. F. Kedir ( $ه)$

WGCFNR, Hawassa University, Shashemene, Ethiopia

Central Ethiopia Environment and Forest Research Center, Addis Ababa, Ethiopia 
was pyrolyzed in assembled setup of tubular furnace using standard laboratory techniques. The bio-oil and bio-char yields were $21.1-42.87 \%(\mathrm{w} / \mathrm{w})$ and $23.23-$ $36.40 \%(\mathrm{w} / \mathrm{w})$, respectively. The bio-oil yield of Acacia seyal, Dodonea angustifolia, Euclea schimperi, Eucalyptus globulus, Casuarina equisetifolia, and Grevillea robusta were over $36 \%$ (w/w), which make the total yield of biooil and bio-char over $62 \%(\mathrm{w} / \mathrm{w})$ of the biomass samples instead of the $12 \%$ conversion efficiency in traditional carbonization. The calorific value of firewood was 16.31-19.66 $\mathrm{MJ} \mathrm{kg}^{-1}$ and bio-oil was 23.3-33.37 $\mathrm{MJ} \mathrm{kg}^{-1}$. The use of bio-oil for household energy and bio-char for carbon storage reduced end use emission by $71.48-118.06 \%$, which could increase adaptation to climate change in comparison to open stove firewood by using clean fuel and reducing indoor pollution.

\section{Keywords}

Bio-char $\cdot$ Bio-oil $\cdot$ Deforestation $\cdot$ End use emission $\cdot$ Woody biomass

\section{Introduction}

The adaptation and mitigation of climate change and energy security requires alternative energy sources that reduce emission of greenhouse gasses (GHG) in the place of fossil fuel dominant economy of the world (Krajnc et al. 2014). Liquid biofuel production from biomass pyrolysis is new form of the old technology that reduces waste and improves the low bulk density, high moisture content, hydrophilic nature, and low calorific value of firewood (Arias et al. 2008). Pyrolysis is a thermochemical process of converting biomass in to solid bio-char, liquid bio-oil (also called pyrolysis oil), and syngas in the absence of oxygen at $300-1000{ }^{\circ} \mathrm{C}$, heating rate $0.1-1000{ }^{\circ} \mathrm{C} \mathrm{s}^{-1}$, and vapor residence time 0.5-1800 s (Granada et al. 2013). Pyrolysis of dry biomass $\left(\mathrm{C}_{6} \mathrm{H}_{10} \mathrm{O}_{5}\right)$ produces combustible gases $\left(\mathrm{H}_{2}, \mathrm{CH}_{4}, \mathrm{CO}\right)$ and noncombustible gases $\left(\mathrm{CO}_{2}\right.$ and $\left.\mathrm{H}_{2} \mathrm{O}\right)$ resulting in condensable gases forming bio-oil $\left(\mathrm{C}_{6} \mathrm{H}_{8} \mathrm{O}\right.$ with $\left.\mathrm{H}_{2} \mathrm{O}\right)$ (Cordeiro 2011). High heating rates above $500{ }^{\circ} \mathrm{C}$ and short vapor residence time gives more pyrolysis oil; and low temperature below $400{ }^{\circ} \mathrm{C}$ produces more bio-char (Xiu and Shahbazi 2012).

Feedstocks for pyrolysis can be a variety of woody and non-woody biomasses, forest products, solid organic wastes, forest/agricultural residues, paper and cardboard except toxic biomasses that have heavy metals, polyaromatic hydrocarbons, and dioxins (Garcia-Perez 2008).

The calorific value of bio-oil can be chemically upgraded to $44 \mathrm{MJ} \mathrm{kg}^{-1}$ (Elliot 2012). Firewood combustion pollutes indoor air and affects health but bio-oil has no significant health, environment, or safety risks and its GHG emission is lower than petro diesel and gasoline (Shimelis 2011).

Bio-char and charcoal are similar products of pyrolysis technology that are used for different purpose. Bio-char is charcoal like, fine porous structured, positively charged, high carbon and low moisture containing co-product of bio-oil but charcoal 
is coarse structure as a sole product. Bio-char could be used for energy supply, soil carbon storage, and fertility amendment but charcoal is usually used for energy.

The pyrolysis of organic matter alters the chemical structure of carbon to aromatic carbon rings called recalcitrant carbon that resist microbial decomposition. Wood biochar stores $25-50 \%$ of its carbon for millennia, 100-1000 years but organic residue compost stores $10-20 \%$ of its carbon from weeks to 5-10 years (Kannan et al. 2013).

Capturing the volatiles during pyrolysis to get bio-oil, in addition to bio-char and syngas instead of mere charcoal, is an increment of conversion efficiency of carbonization in traditional charcoal making (Brown 2009). Charcoal making emits primary GHG of the energy system, carbon monoxide, ethane, pyroacids, tars, heavy oils, and water (Bird et al. 2011). Firewood and charcoal have $\mathrm{CO}_{2}$ emission factors of $112,000 \mathrm{~kg} \mathrm{TJ}^{-1}$ on net calorific value basis (IPCC 2006). About $1788 \pm 337 \mathrm{~g}$ $\mathrm{CO}_{2}$ and $32 \pm 5 \mathrm{~g} \mathrm{CH}_{4}$ per kilogram of charcoal are produced, which varies with different vegetation parts and burning conditions (Chidumayo and Gumbo 2013). In charcoal making the three steps include wood sourcing, carbonization, and end use, and the emission is $29-61 \%, 28-61 \%$, and $9-18 \%$, respectively (FAO 2017).

Climate change adaptation to energy is the adjustment in natural or human systems in response to actual or expected energy deficit of climatic stimuli or their effects, which moderates harm or exploits beneficial energy production opportunities. Ethiopia in particular and Africa in general have low adaptation capability to climate change (IPCC 2006). The conversion of firewood and charcoal in to multiple products of bio-char, bio-oil, and syngas reduces consumption of biomass that reduces deforestation and increases income sources in order to adapt to climate change. In Ethiopia and elsewhere in Africa, adapting technology for alternative sources of bioenergy is one of the strategies of climate change adaptation (FAO 2017). Environmental sustainability could be achieved by local management of firewood saving and macro policy adjustment in order to promote the sustainability of land resources and climate change adaptation (Eze et al. 2020). Therefore, developing biomass saving technologies like pyrolysis is important for climate change adaptation and mitigation.

Pyrolysis oil during biomass carbonization can be produced over a wider range of temperature above $300{ }^{\circ} \mathrm{C}$ by screening a large number of biomass yielding trees (Xiu and Shahbazi 2012). According to Okoroigwe et al. (2015) tropical woody biomass produces up to $66 \%(\mathrm{w} / \mathrm{w})$ bio-oil for energy and it contains industrially useful chemicals. Bio-oil production is an attractive venture with significant commercial application and value, and dry feed can produce up to $80 \%(\mathrm{w} / \mathrm{w})$ bio-oil. However, there is dearth of information on condensing the volatile matters to bio-oil, especially at $600{ }^{\circ} \mathrm{C}$ and residence time of $2 \mathrm{~s}$ in Ethiopia for firewood species, except Catha edulis (Yishak 2014). In fact, it is studied that biomass residues at $600^{\circ}$ $\mathrm{C}$ has high recalcitrant character and low volatile nature (Jindo et al. 2014). One of the most important characteristics of biomass fuel is heating value which can be determined experimentally by adiabatic bomb calorimeter (Sheng and Azevedo 2005), which was not available for many of the firewood tree species in Ethiopia. The purpose of the present study was to inform tree selection in plantation development by the bio-oil and bio-char yield, and by their carbon storage potential in selected firewood utilizing rural households of Southern Ethiopia. 


\section{Material and Methods}

\section{Description of the Study Area}

Biomass samples of fire wood species were collected in Southern Ethiopia, three agro-ecologies of Enemorina Ener district (county). From each agro-ecology a representative peasant association (PA) or Kebele (lowest administrative unit) was sampled. In lowland agro-ecology, 500-1600 m altitude above sea level (asl), Ener Kola PA; in midaltitude agro-ecology, 1600-2400 m altitude asl, Daemir PA; and in highland agro-ecology, 2400-3200 m asl, Awed PA were selected (Fig. 1). The local

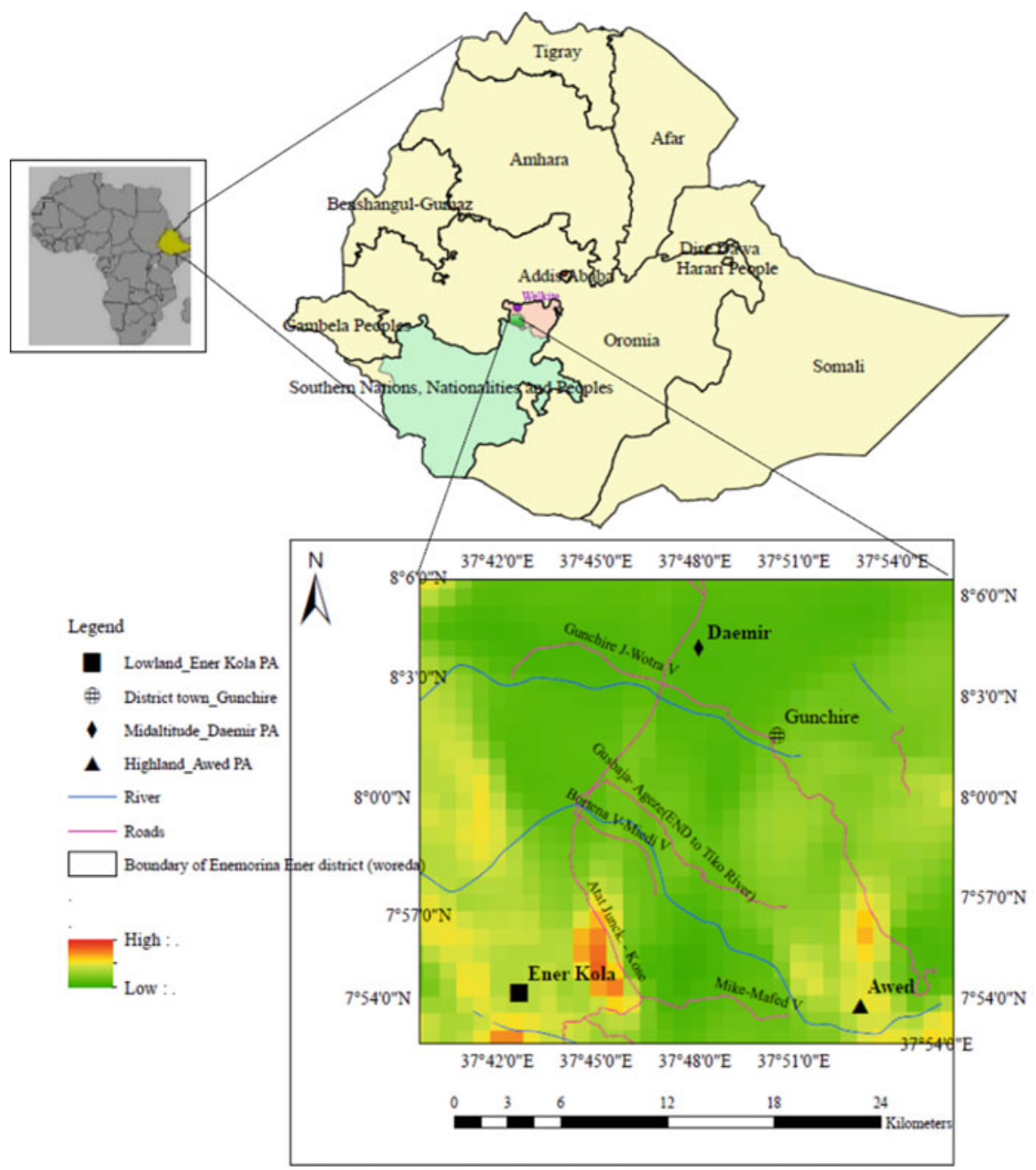

Fig. 1 Location map of most samples collected areas. (The legend and scale refers only to the three studied peasant associations or Kebeles and nearby features) 
people had been practicing mixed farming, trading, and pottery work. The main fuel for cooking was firewood with or without kerosene light.

\section{Methods of Data Collection and Analyses}

\section{Field Sample Collection}

Woody biomass samples were collected from the selected PAs after interviewing 5-10 key informants, and district energy offices about the preferred firewood tree species that ranked $1-5$. The most preferred tree species were selected for pyrolysis test in each agro-ecology; seven species in lowland and midaltitude each and one species in highland. Additional samples from two species (Catha edulis and Prosopis juliflora) were obtained from other places (Table 1) because of their abundance and common firewood value for comparison purposes, making a total of 17 species. That is $C$. edulis is abundant throughout Ethiopia and P. juliflora is an invasive species used for charcoal making in North Eastern Ethiopia. The family, diameter at breast height $(\mathrm{DBH})$, and total mean height $(H)$ of the selected species are given in Table 1.

From the 15 tree species in the forest, three standing trees were randomly selected and cut from each. Then the wood without debarking was chipped in to $1-5 \mathrm{~cm}$ long pieces by excluding branches ( $\leq 5 \mathrm{~cm}$ diameter) and leaves. In $C$. edulis, leafy residues and in $C$. megalocarpus, fruit pod were collected. Then the 17 tree species biomass samples were air dried, separated from any impurities, ground, and sieved by $1 \mathrm{~mm}$ sieve size.

\section{Experimental Analyses}

Pure, composite, ground, dry biomass samples of $150 \mathrm{~g}$ were pyrolyzed in assembled setup of tubular furnace in three replications. The pyrolysis was done at $600{ }^{\circ} \mathrm{C}$ temperature, at a heating rate of $100{ }^{\circ} \mathrm{C} \mathrm{min}^{-1}$ and $2 \mathrm{~s}$ vapor residence, using 1.5 atmosphere inert nitrogen gas with $20-25 \mathrm{~mL} \mathrm{~min}^{-1}$ flow rate. The setup consisted of feeder, reactor, glass liquid collecting condenser, and chiller (Fig. 2). Only bio-oil and bio-char were collected. The weight of bio-char and bio-oil was measured with balance (Adam Lab.equipment Leicester LE67FT-England, $0.001 \mathrm{~g}$ ) and volume by graduated cylinder. The yield of bio-char and bio-oil was determined from the proportion of dried biomass feedstock pyrolyzed (Eq. 1) and loss by deduction (Eq. 2). The percentage throughout this chapter is given as (\%) for percent weight to weight $(\%, \mathrm{w} / \mathrm{w})$ or $\%(\mathrm{w} / \mathrm{w})$ or $\%$, unless otherwise specified as percent volume to volume as $(\%, \mathrm{v} / \mathrm{v})$ or $\%(\mathrm{v} / \mathrm{v})$.

$$
\begin{aligned}
\text { Yield of biooil or biochar }\left(\%, \frac{w}{w}\right)= & \left(\frac{W \text { of biooil or biochar }(g)}{W \text { of pyrolysed feedstock }(g)}\right) \\
& \times 100
\end{aligned}
$$

$$
\operatorname{Biochar}\left(\%, \frac{\mathbf{w}}{\mathbf{w}}\right)+\operatorname{Biooil}\left(\%, \frac{\mathbf{w}}{\mathbf{w}}\right)+\text { NCG }\left(\%, \frac{\mathbf{w}}{\mathbf{w}}\right)=\mathbf{1 0 0}\left(\%, \frac{\mathbf{w}}{\mathbf{w}}\right)
$$


Table 1 Description of sampled tree species for firewood, bio-oil, and bio-char production

\begin{tabular}{|c|c|c|c|c|c|}
\hline \multirow[b]{2}{*}{ Species } & \multirow[b]{2}{*}{ Family } & \multicolumn{3}{|c|}{ Sample of collection } & \multirow[b]{2}{*}{ Sources } \\
\hline & & $\begin{array}{l}\text { Agro- } \\
\text { ecology }\end{array}$ & $\begin{array}{l}\text { Mean } \\
\text { DBH } \\
(\mathrm{cm})\end{array}$ & $\begin{array}{l}\text { Mean } \\
H(\mathrm{~m})\end{array}$ & \\
\hline Acacia albida (Delile) Chev. & Fabaceae & Lowland & 16.07 & 12.3 & $\begin{array}{l}\text { Bekele } \\
(2007)\end{array}$ \\
\hline Acacia seyal Delile & - & Lowland & 17.8 & 14.1 & - \\
\hline $\begin{array}{l}\text { Acokanthera schimperi (A. } \\
\text { DC.) Schweinf. }\end{array}$ & Apocynaceae & Lowland & 10.73 & 7.9 & - \\
\hline $\begin{array}{l}\text { Combretum collinum, } \\
\text { Fresen. }\end{array}$ & Combretaceae & Lowland & 10.08 & 6.9 & - \\
\hline $\begin{array}{l}\text { Euclea schimperi (A.DC.) } \\
\text { Dandy }\end{array}$ & Ebenaceae & Lowland & 11.97 & 10.5 & - \\
\hline Casuarina equisetifolia $\mathrm{L}$. & Casuarinaceae & Lowland & 21.3 & 15.5 & - \\
\hline Dodonaea angustifolia L.f. & Sapindaceae & Lowland & 4.12 & 4.00 & - \\
\hline $\begin{array}{l}\text { Acacia abyssinica Hochst. } \\
\text { ex Benth }\end{array}$ & Fabaceae & Midaltitude & 24.5 & 12.0 & - \\
\hline Acacia decurrens Willd. & Fabaceae & Midaltitude & 27.5 & 11.5 & - \\
\hline Cupressus lusitanica Mill. & Cupressaceae & Midaltitude & 24.6 & 15.5 & - \\
\hline Catha edulis (Vahl.) Endl. & Celastraceae & Midaltitude & - & - & - \\
\hline $\begin{array}{l}\text { Eucalyptus camaldulensis } \\
\text { Dehnh. }\end{array}$ & Myrtaceae & Midaltitude & 21.5 & 16.0 & - \\
\hline $\begin{array}{l}\text { Grevillea robusta A.Cunn. } \\
\text { ex R.Br. }\end{array}$ & Proteaceae & Midaltitude & 20.5 & 14.5 & - \\
\hline $\begin{array}{l}\text { Pinus patula Schldl. et } \\
\text { Cham. }\end{array}$ & Pinaceae & Midaltitude & 19.3 & 15 & - \\
\hline Eucalyptus globulus Labill. & Myrtaceae & Highland & 27.3 & 12.5 & - \\
\hline Prosopis julifolra (Sw.) DC. & Fabaceae & Afar & 22.5 & 17.5 & - \\
\hline $\begin{array}{l}\text { Croton megalocarpus } \\
\text { Hutch. }\end{array}$ & Euphorbiaceae & $\begin{array}{l}\text { Hawassa } \\
\text { city }\end{array}$ & 10.5 & 6.5 & $\begin{array}{l}\text { Aliyu et } \\
\text { al. } \\
(2010)\end{array}$ \\
\hline
\end{tabular}

where $W$ is weight; NCG is non-condensable gas by considering that all condensable gases were condensed.

The bio-oil was degummed in $3 \%(\mathrm{v} / \mathrm{v})$ distilled water and centrifuged at $2000 \mathrm{rpm}$ for $20 \mathrm{~min}$. The moisture content was determined gravimetrically by taking $5 \mathrm{~g}$ bio-oil by heating at $105{ }^{\circ} \mathrm{C}$ in oven up to constant weight (Eq. 3).

$$
\operatorname{MC}\left(\%, \frac{\mathbf{w}}{\mathbf{w}}\right)=\left(\frac{\left(\boldsymbol{W} \text { of initial sample }(g)-W \text { of sample at } 105^{\circ} \mathbf{C}(g)\right)}{W \text { of initial sample }(g)}\right) \times 100
$$

where $\mathrm{MC}$ is moisture content; $W$ is weight. 


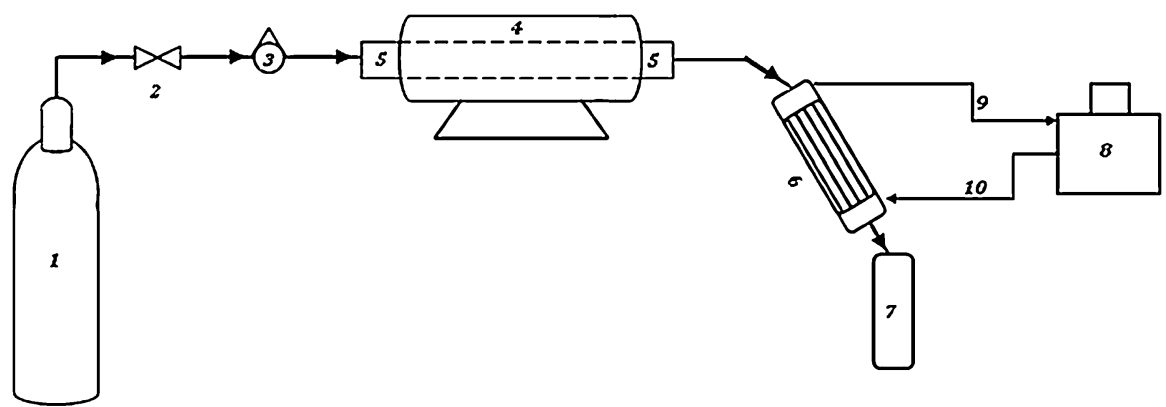

Fig. 2 Simplified system of pyrolysis, assembled setup of tubular furnace Legend (not to scale):

1. $\mathrm{N}_{2}$ gas containing cylinder; 2. Valve; 3 . Pressure gauge; 4 . Tubular furnace; 5 . Stainless steel tube (inserted into the furnace); 6. Glass condenser; 7. Condensate collector; 8. Chiller; 9. Hot water to chiller; 10 . Cooling water $\left(\right.$ at $\left.4{ }^{\circ} \mathrm{C}\right)$ to condenser

The bio-oil and parent firewood Gross Calorific Value (GCV) was determined by adiabatic oxygen bomb calorimeter (Parr ${ }^{\circledR}$ model no.1241EF adiabatic calorimeter S.no. 5172, 115 v, 50 Hz, 2.0 Amps, Parr Instrument Company). About $1 \mathrm{~g}$ sample and oxygen filled bomb at 30 atmospheres were used. GCV was converted to net calorific value (NCV) by multiplying with 0.95 and 0.80 for oil and dry woody biomass, respectively (Forest Products Laboratory 2004). Ash content of firewood and bio-oil was determined by burning $5 \mathrm{~g}$ sample in furnace at $600{ }^{\circ} \mathrm{C}$ for $4 \mathrm{~h}$.

Bio-char samples were characterized using proximate analysis (ASTM 1989) to obtain fixed carbon, moisture content (D3173), ash content (D3174), and volatile matter (D3175). Moisture content of bio-char was determined by drying $1 \mathrm{~g}$ initial sample in oven at $105{ }^{\circ} \mathrm{C}$ to constant weight for $3 \mathrm{~h}$ (Eq. 3); volatile matter by heating $1 \mathrm{~g}$ moisture free sample at $950^{\circ} \mathrm{C}$ for $6 \mathrm{~min}$ (Eq. 4); ash content by heating $1 \mathrm{~g}$ sample at $750^{\circ} \mathrm{C}$ for $3 \mathrm{~h}$ (Eq. 5) and fixed carbon by deduction (Eq. 6).

$$
\operatorname{Vm}\left(\%, \frac{\mathbf{w}}{\mathbf{w}}\right)=\left(\frac{W \text { of sample at } 105^{\circ} \mathbf{C}(g)-W \text { of sample at } 950^{\circ} \mathrm{C}(g)}{W \text { of initial sample }(g)}\right) \times 100
$$

$$
\operatorname{Ash}(A)\left(\%, \frac{\mathbf{w}}{\mathbf{w}}\right)=\left(\frac{W \text { of sample at } 750^{\circ} \mathrm{C}(\mathrm{g})}{W \text { of initial sample }(\mathrm{g})}\right) \times 100
$$

Fixed carbon of biochar $\left(\%, \frac{\mathbf{w}}{\mathbf{w}}\right)=(\mathbf{1 0 0}-(\mathbf{M C}, \%+\mathbf{V m}, \%+\boldsymbol{A}, \%))$

where $\mathrm{MC}$ is moisture content; $W$ is weight; $\mathrm{Vm}$ is volatile matter; $A$ is ash content

The common $\mathrm{GHG}\left(\mathrm{CO}_{2}, \mathrm{CH}_{4}\right.$, and $\left.\mathrm{N}_{2} \mathrm{O}\right)$ emissions in rural wooden houses were determined based upon NCV (IPCC 2006) of bio-oil and firewood with or without kerosene. Although emission exists throughout the life cycles of these fuels, from 
Table 2 Emission factors and global warming potential of common GHGs from different fuels

\begin{tabular}{|c|c|c|c|c|c|}
\hline \multirow[b]{2}{*}{$\begin{array}{l}\text { Type of } \\
\text { GHG }\end{array}$} & \multicolumn{4}{|c|}{$\begin{array}{l}\text { Residential source of Gas Emission Factors on a net calorific } \\
\text { basis (Stationary Combustion) (IPCC 2006) }\left(\mathrm{kg} \mathrm{TJ}^{-1}\right)\end{array}$} & \multirow[b]{2}{*}{$\begin{array}{l}\text { GWP (100-year } \\
\text { time horizon) }\end{array}$} \\
\hline & $\begin{array}{l}\text { Firewood in } \\
\text { conventional } \\
\text { stove }\end{array}$ & $\begin{array}{l}\text { Bio-oil (other } \\
\text { liquid biofuels) }\end{array}$ & Charcoal & $\begin{array}{l}\text { Other } \\
\text { kerosene }\end{array}$ & \\
\hline $\mathrm{CO}_{2}$ & 112000 & 79600 & 112000 & 71900 & 1 \\
\hline $\mathrm{CH}_{4}$ & 210 & 10 & 330.5 & 10 & 23 \\
\hline $\mathrm{N}_{2} \mathrm{O}$ & 4 & 0.6 & 1.6 & 0.6 & 296 \\
\hline
\end{tabular}

planting, woody biomass harvesting to consumption, the present study's concern of indoor pollution reduction dealt the emission only at the end use or consumption. The IPCC default emission factors were applied (Eqs. 7 and 8). The GHGs were converted to carbon dioxide equivalent $\left(\mathrm{CO}_{2}^{-\mathrm{e}}\right)$ using the global warming potential (GWP) of each gas (Table 2).

The average end use emission of firewood and bio-oil combustion and bio-char soil carbon accumulation was determined. For comparison purpose, the daily consumption of firewood and kerosene at household level in each agro-ecology was obtained from Miftah et al. (2017). It was assumed that a household consumes the same amount of energy in using firewood alone, firewood with kerosene or bio-oil.

The carbon storage of bio-char was determined by its fixed carbon content (Eq. 9). Stable carbon fraction to be stored for over a century used $80 \%$ factor (Roberts et al. 2010). In the presence of modern pyrolysis reactor $75 \%$ bio-oil and $12 \%$ bio-char yield was assumed to be produced from woody biomass (Granada et al. 2013). The total energy of the fuels was determined by the dried weight of the fuel and their calorific value (ASTM 1989).

The emission from firewood combustion in conventional wood stove using IPCC (2006) was calculated as Eq. 7.

$$
\mathrm{Wd} \mathrm{em}=\sum_{i}^{k} \mathrm{Wd} \mathrm{cons}_{(i j k)} \times \mathbf{E F}_{(i j k)} \times \mathbf{G W P}_{(i j k)}
$$

where Wd em is emission of GHG $\left(\mathrm{kgCO}_{2}{ }^{\mathrm{e}-}\right)$ from firewood combustion; Wd cons is firewood consumption in net calorific value $\left(\mathrm{TJkg}^{-1}\right)$; $\mathrm{EF}$ is emission factor of firewood on net calorific value basis $\left(\mathrm{kgTJ}^{-1}\right)$; and GWP is global warming potential of a given gas on 100 years; $i$ is $\mathrm{CO}_{2} ; j$ is $\mathrm{CH}_{4}$, and $k$ is $\mathrm{N}_{2} \mathrm{O}$.

The emission from bio-oil combustion in stove using IPCC (2006) was calculated as Eq. 8.

$$
\text { Bo em. }=\sum_{i}^{k} B \operatorname{cons} s_{(i j k)} \times \mathbf{E F}_{(i j k)} \times \mathbf{G W P}_{(i j k)}
$$

where $\mathrm{Bo}$ em is emission of $\mathrm{GHG}\left(\mathrm{kgCO}_{2}{ }^{\mathrm{e}-}\right)$ from bio-oil combustion; Bo cons is bio-oil consumption in net calorific value ( $\left.\mathrm{TJkg}^{-1}\right)$; $\mathrm{EF}$ is emission factor of bio-oil 
on net calorific value basis $\left(\mathrm{kgTJ}^{-1}\right)$; and GWP is global warming potential of a given gas on 100 years basis; $i$ is $\mathrm{CO}_{2} ; j$ is $\mathrm{CH}_{4}$ and $k$ is $\mathrm{N}_{2} \mathrm{O}$.

Carbon storage in bio-char of organic wastes was calculated as Eq. 9.

$$
\operatorname{Csb}(\boldsymbol{g})=(\text { dry biomass }(\boldsymbol{g})) \times(\text { biochar yield }(\%)) \times(\text { fixed } \boldsymbol{C}(\%))
$$

where Csb is carbon storage in bio-char.

\section{Results}

\section{Bio-oil and Bio-char Yield of Different Woody Biomasses Species}

The bio-oil (Fig. 3) yield of woody biomass samples ranged from 23.03 (\%,w/w) in A. schimperi to $42.9(\%, \mathrm{w} / \mathrm{w})$ in E. globulus which was statistically different at $\mathrm{p}<0.05$ (Table 3). The bio-oil yield of fruit pod of C. megalocarpus was about 21.1 $(\%, w / w)$, lower than the other woody biomasses; and the leaf of $C$. edulis was intermediate about $25.83(\%, \mathrm{w} / \mathrm{w})$. Tree species like E. globulus, A. seyal, D. angustifolia, E. schimperi, and $G$. robusta produced greater amount of bio-oil (Table 3) and highly preferred for firewood (Table 3).

The bio-char (Fig. 4) yield of the biomass samples ranged from $23.2 \%(\mathrm{w} / \mathrm{w})$ in $E$. camaldulensis to $36.4 \%(\mathrm{w} / \mathrm{w})$ in C. edulis which was statistically different at $\mathrm{p}<0.05$ (Table 3). The mass losses of pyrolysis product ranged from $31.23 \%$ (w/w) in E. schimperi to $46.37 \%$ (w/w) in A. schimperi (Table 3), which could be attributed to the specific characteristics of the species.

\section{Calorific Value and Moisture Content of Bio-oil and Bio-char in Comparison with the Parent Firewood}

The calorific value of firewood used for the pyrolysis process ranged from $16.31 \mathrm{MJkg}^{-1}$ (in E. schimperi) to $19.66 \mathrm{MJkg}^{-1}$ (in P. julifolra) at moisture content

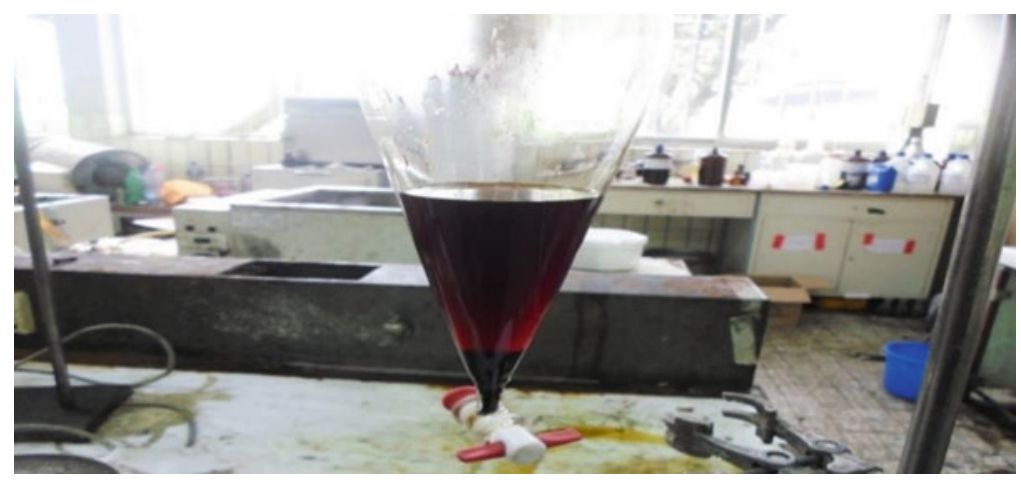

Fig. 3 Bio-oil from pyrolysis of woody biomass 
Table 3 Bio-oil and bio-char yield of different woody plant species

\begin{tabular}{|c|c|c|c|}
\hline \multirow[b]{2}{*}{ Species } & \multicolumn{2}{|c|}{ Yield (Mean \pm Stand. err.) $(\%, w / w)$} & \multirow[b]{2}{*}{ Priority as firewood ${ }^{\mathrm{g}}$} \\
\hline & Bio-oil & Bio-char & \\
\hline A. abyssinica & $29.067 \pm 3.254^{\mathrm{abcd}}$ & $31.367 \pm 1.717^{\mathrm{bc}}$ & 1 \\
\hline A. albida & $33.433 \pm 1.802^{\mathrm{abcd}}$ & $30.567 \pm 0.769^{\mathrm{bc}}$ & 1 \\
\hline A. decurrens & $33.533 \pm 3.641^{\mathrm{abcd}}$ & $30.233 \pm 0.555^{\mathrm{bc}}$ & 2 \\
\hline A. schimperi & $23.033 \pm 2.567^{\mathrm{ab}}$ & $30.600 \pm 0.794^{\mathrm{bc}}$ & 4 \\
\hline A. seyal & $39.000 \pm 1.808^{\mathrm{cd}}$ & $27.133 \pm 0.736^{\mathrm{ab}}$ & 1 \\
\hline C. collinum & $31.633 \pm 3.537^{\mathrm{abcd}}$ & $30.933 \pm 1.212^{\mathrm{bc}}$ & 1 \\
\hline C. edulis $^{\mathrm{e}}$ & $25.833 \pm 2.634^{\mathrm{abc}}$ & $36.400 \pm 0.208^{\mathrm{d}}$ & 5 \\
\hline C. equisetifolia & $36.067 \pm 4.390^{\mathrm{bcd}}$ & $27.100 \pm 0.173^{\mathrm{ab}}$ & 1 \\
\hline C. lusitanica & $34.167 \pm 2.195^{\mathrm{abcd}}$ & $27.500 \pm 0.173^{\mathrm{ab}}$ & 3 \\
\hline C. megalocarpus ${ }^{\mathrm{f}}$ & $21.100 \pm 1.200^{\mathrm{a}}$ & $33.300 \pm 1.700^{\mathrm{c}}$ & 3 \\
\hline D. angustifolia & $38.033 \pm 0.219^{\mathrm{cd}}$ & $24.633 \pm 0.186^{\mathrm{a}}$ & 1 \\
\hline E. camaldulensis & $32.767 \pm 1.139^{\mathrm{abcd}}$ & $23.233 \pm 0.841^{\mathrm{a}}$ & 1 \\
\hline E. globulus & $42.867 \pm 0.888^{\mathrm{d}}$ & $25.733 \pm 1.033^{\mathrm{a}}$ & 1 \\
\hline E. schimperi & $37.133 \pm 2.118^{\mathrm{cd}}$ & $31.633 \pm 1.650^{\mathrm{bc}}$ & 1 \\
\hline G. robusta & $38.800 \pm 3.623^{\mathrm{cd}}$ & $25.267 \pm 0.219^{\mathrm{a}}$ & 2 \\
\hline P. juliflora & $31.367 \pm 4.296^{\mathrm{abcd}}$ & $30.767 \pm 0.536^{\mathrm{bc}}$ & 3 \\
\hline P. patula & $27.800 \pm 1.600^{\mathrm{abc}}$ & $27.600 \pm 1.900^{\mathrm{ab}}$ & 3 \\
\hline
\end{tabular}

Note: ${ }^{\mathrm{a}, \mathrm{b}, \mathrm{c},}$ and ${ }^{\mathrm{d}}$ are statistically different at $\mathrm{p}<0.05$ of ANOVA

${ }^{\mathrm{e}}$ Leaves

${ }^{\mathrm{f}}$ Fruit pod

${ }^{\mathrm{g}}$ Priority 1 is highly preferred and 5 is not

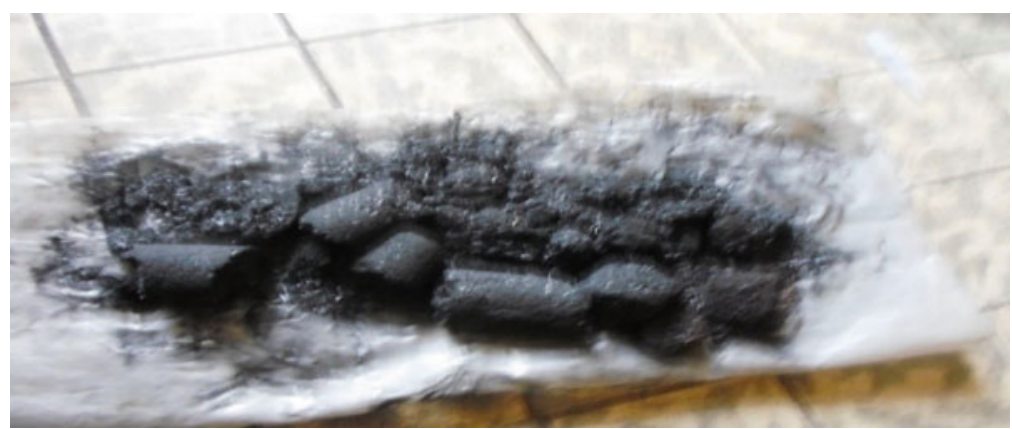

Fig. 4 Bio-char from pyrolysis of woody biomass

of 7.92-10.22 (\%, w/w) (Fig. 5). Firewood from D. angustifolia, E. camaldulensis, G. robusta, A. decurrens, and E. globulus had calorific value above $18 \mathrm{MJ} \mathrm{kg}^{-1} . C$. edulis leafy residues had comparable calorific value with the other firewood species (Fig. 5), but not used as firewood (Table 3 ) because of its smoke. The calorific value of bio-oil ranged from $21.43 \mathrm{MJkg}^{-1}$ (in A. albida) to $33.37 \mathrm{MJkg}^{-1}$ (in E. globulus) (Fig. 5). 


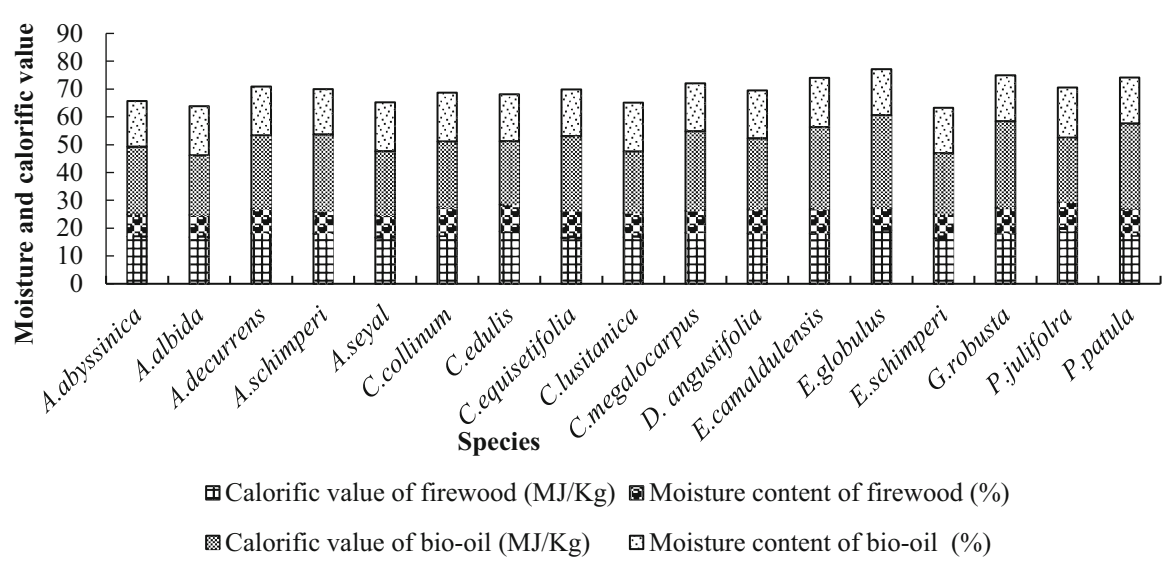

Fig. 5 The mean calorific value of parent firewood, bio-char, and bio-oil of a given plant species

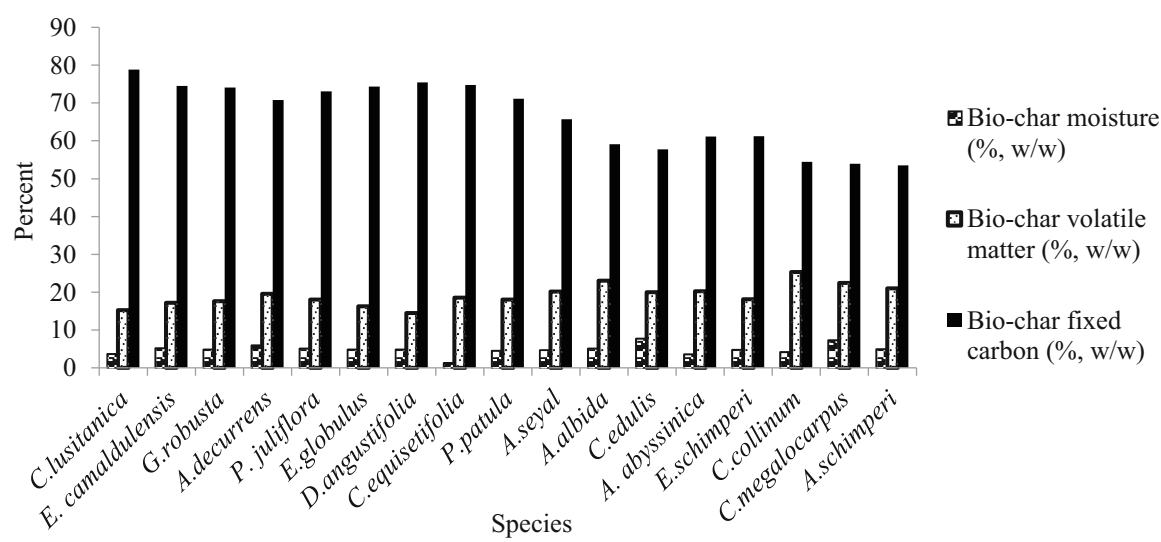

Fig. 6 Mean fixed carbon, volatile, and moisture content of bio-char

\section{Fixed Carbon, Volatile Matter, and Moisture Content of Different Tree Species Bio-chars}

The fixed carbon content of bio-chars of the different tree species ranged from 53.48 $(\%, \mathrm{w} / \mathrm{w})$ (in A. schimperi) to $78.85(\%, \mathrm{w} / \mathrm{w})$ (in C. lusitanica); and volatile matter from $14.52(\%, \mathrm{w} / \mathrm{w})$ (in D. angustifolia) to $25.31(\%, \mathrm{w} / \mathrm{w})($ C. collinum) (Fig. 6).

\section{Ash Content of Firewood Feedstock, and Bio-oil and Bio-char}

The percentage of the ash content of the different tree species firewood and bio-oil was not consistently increasing or decreasing (Table 4). The ash in bio-char ranged from $2.27(\%, \mathrm{w} / \mathrm{w})$ in C. lusitanica to $20.65(\%, \mathrm{w} / \mathrm{w})$ in $A$. schimperi. In firewood the ash content ranged from $0.434(\%, \mathrm{w} / \mathrm{w})$ in E. camaldulensis to $8.418(\%, \mathrm{w} / \mathrm{w})$ in E. schimperi. The lowest proportion of ash was obtained in bio-oil, ranging from 
$0.135 \%$ in G. robusta to $0.892 \%$ in C. equisetifolia. As the ash content of the firewood increases the ash content of the bio-char also increased (Table 4).

\section{The Potential of Pyrolysis Oil and Bio-char in Reducing Firewood End Use Emission}

Rural households were using firewood and kerosene as energy sources. In the presence of kerosene, the amount of firewood biomass used was reduced, but both biomass and kerosene together during consumption emitted annually about 2.323-4.509 $\mathrm{t} \mathrm{CO}_{2}{ }^{\mathrm{e}}$ in each household. The end use emission from fire wood combustion was 2.335-4.527 $\mathrm{t} \mathrm{CO}_{2}{ }^{\mathrm{e}}$ year ${ }^{-1}$ (Fig. 7), which could be reduced to 1.88-3.645 $\mathrm{t} \mathrm{CO}_{2}{ }^{\mathrm{e}}$ year ${ }^{-1}$ in bio-oil heating in each household of the studied PAs. Moreover, bio-oil production has corresponding bio-char that can store carbon 1.214-4.363 $\mathrm{t} \mathrm{CO}_{2}{ }^{\mathrm{e}}$ year $^{-1}$ (Fig. 7) that makes the net emission of 0.67 to net storage of $0.72 \mathrm{t} \mathrm{CO}_{2}{ }^{\mathrm{e}}$ year $^{-1}$. The pyrolysis in the present study that produced bio-oil yield of $21-42.87(\%, \mathrm{w} / \mathrm{w})$ as alternative energy for a household cooking and bio-char for carbon storage reduced end use emission by $71.48-118.06 \%$ in each household of the PAs when compared with the emission by firewood (Fig. 7). In using bio-char that produced $23.23-36.4 \%$, w/w (Table 3) from a household firewood for soil amelioration can store $0.27-0.95 \mathrm{t} \mathrm{C}$ year $^{-1}$ for over a century (Fig. 8).

Table 4 The mean ash content of firewood, bio-oil, and bio-char of different tree species

\begin{tabular}{|c|c|c|c|}
\hline \multirow[b]{2}{*}{ Species } & \multicolumn{3}{|c|}{ Mean ash $(\%, w / w)$} \\
\hline & Firewood & Bio-oil & Bio-char \\
\hline A. abyssinica & 4.586 & 0.531 & 15.03 \\
\hline A. albida & 4.421 & 0.567 & 12.80 \\
\hline A. decurrens & 1.418 & 0.688 & 3.72 \\
\hline A. schimperi & 4.382 & 0.758 & 20.65 \\
\hline A. seyal & 3.471 & 0.794 & 9.45 \\
\hline C. collinum & 7.358 & 0.588 & 16.11 \\
\hline C. edulis ${ }^{\mathrm{a}}$ & 7.816 & 0.787 & 14.51 \\
\hline C. equisetifolia & 1.788 & 0.892 & 5.36 \\
\hline C. lusitanica & 1.049 & 0.685 & 2.27 \\
\hline C. megalocarpus ${ }^{\mathrm{b}}$ & 6.159 & 0.724 & 16.38 \\
\hline D. angustifolia & 1.506 & 0.727 & 5.17 \\
\hline E. camaldulensis & 0.434 & 0.618 & 3.15 \\
\hline E. globulus & 3.594 & 0.352 & 4.54 \\
\hline E. schimperi & 8.418 & 0.775 & 15.98 \\
\hline G. robusta & 0.742 & 0.135 & 3.50 \\
\hline P. juliflora & 1.748 & 0.831 & 3.87 \\
\hline P. patula & 7.459 & 0.146 & 6.36 \\
\hline
\end{tabular}

${ }^{\mathrm{a}}$ Leaves

${ }^{\mathrm{b}}$ Fruit pod 


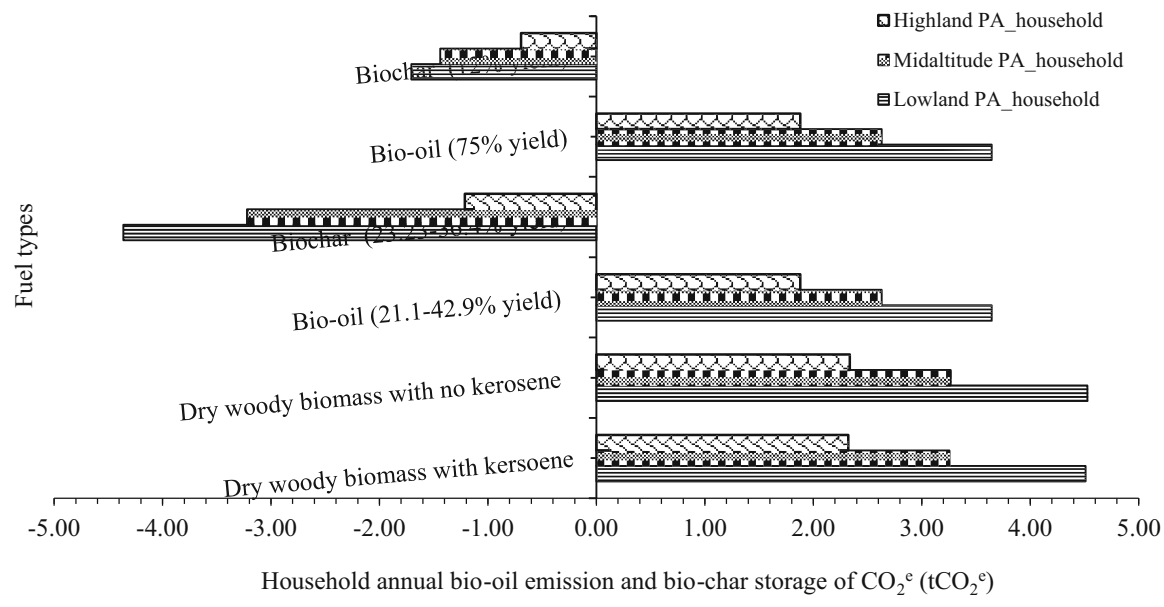

Fig. 7 Emission and carbon storage of fuels at household level with similar gross heating value. (Note: Negative $\mathrm{X}$-axis indicates the $\mathrm{CO}_{2}{ }^{\mathrm{e}}$ stored in bio-char; positive $\mathrm{X}$-axis indicates the $\mathrm{CO}_{2}{ }^{\mathrm{e}}$ emission)

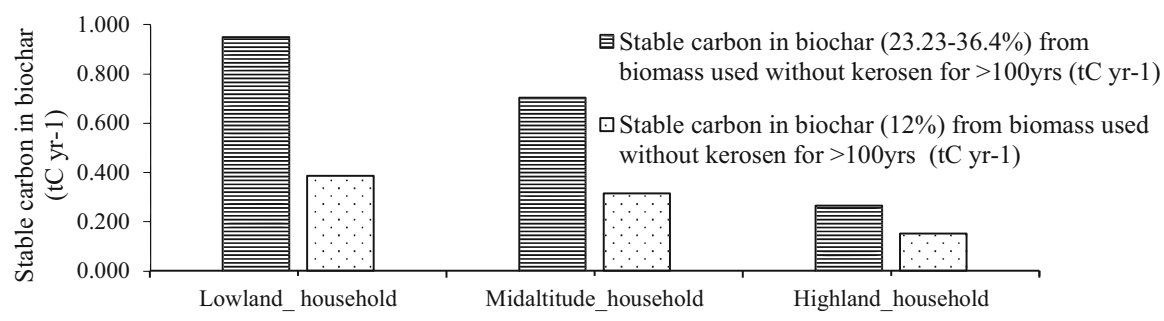

Rural household in agro-ecology

Fig. 8 Stable carbon storage in bio-char in converting firewood to bio-oil

\section{Discussion}

The use of pyrolysis technology to reduce the wastage of biomass and diversify products like biochar, bio-oil, and syngas increases adaptation and mitigation to climate change (Shackley et al. 2012). Greater bio-oil yield was obtained from locally preferred firewood species that also had less bio-char and less parent material ash (Tables 3 and 4). E. globulus was the highest bio-oil yielder (43\%,w/w) and locally preferred for firewood (Table 3 ). This was confirmed by other studies, as the amount of bio-oil yield of pyrolysis of E. globulus and pine wood was $75(\%, \mathrm{w} / \mathrm{w})$ at $500{ }^{\circ} \mathrm{C}$, at a rate of $1000^{\circ} \mathrm{C} \mathrm{s}^{-1}$ and $1 \mathrm{~s}$ vapor residence time (Granada et al. 2013). Maximum bio-oil yield of about $70-80 \%$ on dry basis of woody biomass pyrolysis was obtained at $480-530{ }^{\circ} \mathrm{C}$ from previous other studies. The temperature limit of $600{ }^{\circ} \mathrm{C}$ used in the present study was in line with other studies for lignocellulosic 
biomass (Amutio et al. 2012). The overall yield of bio-oil was similar with other studies of different species; however, different tree species could require different levels of temperature, rate of heat, and vapor residence time (Okoroigwe et al. 2015), which require further study for each species.

Bio-oil and bio-char production of woody biomass depends on the structural components, cellulose, hemicellulose, and lignin. According to Akhtar and Amin (2011), higher content of cellulose and hemicelluloses favors formation of bio-oil; and higher lignin content favors formation of bio-char. E. globulus that produced the highest bio-oil (Table 3) contained 50\% (w/w) cellulose (Dmitry and Neto 2007), than G. robusta, 46.38\% (w/w) (Madan and Roymoulik 1990). However, the cellulose content of $C$. edulis in Yishak (2014) was 59\% but had low bio-oil amount $(25.83 \%, \mathrm{w} / \mathrm{w})$ in the present study and requires further study. The ash content of bio-oil of the woody biomasses was lower than other studies (Table 4), which could be because of the lower ash content of the parent firewood (Table 4). The highest biochar obtained from leaf residue of $C$. edulis (Table 3) could be attributed to the highest extractive and lignin content, about 31.5\% (Yishak 2014). G. robusta was a recently introduced species when compared with a century old E. globulus and $E$. camaldulensis in the study area. Most of the fuel characteristics of $G$. robusta bio-oil were comparable to E. globulus, and therefore, it can be used as firewood plantation tree species in the area.

The calorific value of the bio-oil in the present study was relatively higher than other studies (Oduor and Githiomi 2013) (Fig. 5), which might be because of centrifuging the bio-oil with distilled water and subsequent dehydration. Better calorific value was obtained from the bio-oil than the parent firewood. Depending on the level of technology, the same wood from a tree species can be used in three different forms of biomass fuels including firewood, bio-oil (bio-char), or charcoal. The processing from firewood to bio-oil diversifies income source. The production processes of bio-char and charcoal have similar pyrolysis technique with similar calorific value, about 28-30 $\mathrm{MJ} \mathrm{kg}^{-1}$ (Namaalwa et al. 2007). Therefore, in order to reduce the deforestation rate, conversion to bio-oil and bio-char increases the efficiency of biomass use and improves the adaptation to climate change.

In the bio-char, the amount of fixed carbon and volatile matter at moisture content 1.3-7.74 (\%,w/w) (Fig. 6) were comparable to other studies. Volatile matter of less than $20 \%$ and bio-char fixed carbon content over $50 \%$ from all of the 17 species (Fig. 6) obtained in the present study indicated the absence of labile carbon and their potential of long time carbon storage (Awad et al. 2012).

Since GHG emissions from bio-oil and firewood are taken up by the re-growing trees, there is no net emission except end use emission as indoor pollutant smoke. The end use emission as indoor pollution of bio-oil is lower than the firewood combustion because in bio-oil non-condensable gases are removed in manufacturing areas. Therefore, the use of bio-oil is safer than the direct use of firewood because of the reduction of smoke (Demirbas 2004).

The carbon storage in bio-char is a synergy to afforestation and to reduce climate change (Lehmann et al. 2006). The bio-oil and bio-char production technology could also use cheap sources of feedstock like organic wastes to reduce pressure on forests, 
to dispose waste and retard emission. Moreover, the reduction in forest biomass utilization improves water resources availability, secures clean air to breathe, and generates income by selling the forest products so that climate change adaptation could be improved.

\section{Conclusion and Recommendation}

The pyrolysis of woody biomasses of different tree species produced different quantity and quality of bio-oil and bio-char yield. Since the bio-oil and bio-char yield of A. seyal, D. angustifolia, E. schimperi, E. globulus, C. equisetifolia, and $G$. robusta was over $62 \%(\mathrm{w} / \mathrm{w})$ of the parent firewood biomass used in pyrolysis, these can be selected for plantation development and climate change adaptation. Centrifuging pyrolysis oil with distilled water and subsequent dehydration resulted in increased calorific value to $33 \mathrm{MJ} \mathrm{kg}^{-1}$ in E. globulus. The production and simultaneous use of bio-oil yield (21.1-42.87\%, w/w) and bio-char yield (23.233$36.40 \%, \mathrm{w} / \mathrm{w}$ ) for household cooking energy and for carbon storage, respectively, instead of firewood reduced end use emission by $71.48-118.06 \%$ in each household of lowland to highland PA of the studied area, which could increase adaptation to climate change by reducing the cost of indoor pollution. Therefore, pyrolysis of biomass generally reduces wood wastage, creates jobs, and provides organic carbon as adaptation to climate change. In order to reduce transport cost of low density and high volume biomass, and to reduce the number of transportation vehicles, it is important to establish small-scale biomass pyrolysis firm in electrified parts of Ethiopia that produce bio-oil and bio-char from woody and non-woody organic wastes to diversify income and to increase the adaptive capacity of the rural people to climate change. Moreover, carbon storage potential of bio-char can be used to improve soil fertility in rural areas as a means of climate change adaptation and mitigation. The tree/shrub species used for making charcoal in Ethiopia are mainly slow growing indigenous species existing in natural forest, and there should be a guiding policy to plant tree species like A. seyal, D. angustifolia, E. schimperi, E. globulus, C. equisetifolia, and G. robusta for charcoal making and to strengthen climate change adaptation.

Acknowledgments The research was financially supported by Hawassa University, Wondo Genet College of Forestry and Natural Resources, Central Ethiopia Environment and Forestry Research Center, and Association of African Universities Small Grant for Post Graduate Theses and Dissertations.

\section{References}

Akhtar J, Amin N (2011) A review on process conditions for optimum bio-oil yield in hydrothermal- liquefaction of biomass. Renew Sust Energ Rev 15:1615-1624

Aliyu B, Agnew B, Douglas S (2010) Croton megalocarpus (Musine) seeds as a potential source of Bio-diesel. Biomass Bioenergy 34(10):1495-1499. https://doi.org/10.1016/j.biombioe.2010.04.026 
Amutio M, Lopez G, Artetxe M, Elordi G, Olazar M, Bilbao J (2012) Influence of temperature on biomass pyrolysis in a conical spouted bed reactor. Resour Conserv Recycl 59:23-31

Arias BR, Pevida CG, Fermoso JD, Plaza MG, Rubiera FG, Pis-Martinez JJ (2008) Influence of torrefaction on the grindability and reactivity of woody biomass. Fuel Process Technol 89 (2):169-175

ASTM (American Society for Testing and Materials) (1989) Annual book of ASTM standards, petroleum products, lubricants and fossil fuels. Sect 5, v 5 Gaseous fuels, coal and coke. ASTM, West Conshohocken. PCN-01-050589-13

Awad YM, Blagodatskaya E, Ok YS, Kuzyakov YY (2012) Effects of polyacrylamide, biopolymer, and biochar on decomposition of soil organic matter and plant residues as determined by ${ }^{14} \mathrm{C}$ and enzyme activities. Eur J Soil Biol 48:1-10

Bekele TA (2007) In: Tengnäs B, Kelbesa E, Demissew S, Maundu P (eds) Useful trees and shrubs of Ethiopia: identification, propagation and management for 17 agroclimatic zones. RELMA in ICRAF Project World Agroforestry Centre, Nairobi, p 559

Bird N, Cowie A, Cherubini F, Jungmeier G (2011) Using a life cycle assessment approach to estimate the net greenhouse gas emissions of bioenergy. IEA bioenergy P 20, www. ieabioenergy.com. Accessed 17 Oct 2019

Brown R (2009) Bio-char production technology. In: Lehmann J, Joseph S (eds) Bio-char for environmental management: science and technology. Earthscan, London, pp 127-146

Chidumayo EN, Gumbo DJ (2013) The environmental impacts of charcoal production in tropical ecosystems of the world. A synthesis. Energy Sustain Dev 17:86-94

Cordeiro LG (2011) Characterização e viabilidade econômica de bagaço de malte oriundo de cervejarias para fins energéticos João pessoa, $120 \mathrm{f}$

Demirbas A (2004) The influence of temperature on the yields of compounds existing in bio-oils obtained from biomass samples via pyrolysis. Fuel Process Technol 88:591-597

Dmitry VE, Neto CP (2007) Recent advances in Eucalyptus wood chemistry: structural features through the prism of technological response. https://www.researchgate.net/publication/ 237632161. Accessed on 16 Nov 2017

Elliot DC (2012) Biomass pyrolysis to liquid fuels in the US 2G 2020, Biofuel Seminar, Helsinki, Finland, August 30, 2012

Eze JN, Ibrahim PA, Tiamiyu SA, Alfa M (2020) Assessment of drought occurrences and its implications on agriculture in Niger State, Nigeria. Discov Agric 6(15):1-10

FAO (Food and Agricultural Organization of the United Nations) (2017) The charcoal transition: greening the charcoal value chain to mitigate climate change and improve local livelihoods, by van Dam Rome J. FAO

Forest Products Laboratory (2004) Fuel value calculator. USDA Forest Service, Forest Products Laboratory, Pellet Fuels Institute, Madison. Available at http://www.fpl.fs.fed.us. Accessed on 17 July 2017

Garcia-Perez M (2008) The formation of polyaromatic and dioxins during pyrolysis: a review of the literature with description of biomass composition, fast pyrolysis technologies and thermochemical reactions. Washington State University. http:/www.pacificbiomass.org/documents/theforma tionofpolyaromatihydrocarbonsanddioxinsduringpyrolysis.pdf. Accessed on 17 July 2017

Granada E, Míguez JL, Febrero L, Collazo J, Eguía P (2013) Development of an experimental technique for oil recovery during biomass pyrolysis. Renew Energy 60:179-184

IPCC (Intergovernmental Panel on Climate Change) (2006) Guidelines for national greenhouse gas inventories, and Emission Factor Data Base (EFDB) version from November 2016, number of emission factors: 16877. Chapter 1, V 2: Energy, Tables 14, 25 \& 29

Jindo K, Mizumoto H, Sawada Y, Sanchez-Monedero MA, Sonoki T (2014) Physical and chemical characterization of biochars derived from different agricultural residues. Biogeosciences 11:6613-6621

Kannan P, Arunachalam P, Prabukumar G, Govindaraj M (2013) Bio-char an alternate option for crop residues and solid waste disposal and climate change mitigation. Afr J Agric Res 8 (21):2403-2412. https://doi.org/10.5897/AJAR12.2083

Krajnc N, Prislan P, Jemec T, Triplat M (2014) Development of biomass trade and logistics centres for sustainable mobilisation of local wood biomass resources - Biomass Trade Centre II: 
publishable report Ljubljana: Gozdarski inštitut Slovenije, 2014 ilustr http://proforbiomed.eu/ sites/default/files/14\%20-\%20Environmental\%20impact.pdf. Accessed on 21 Dec 2016

Lehmann J, Gaunt J, Rondon M (2006) Bio-char sequestration in terrestrial ecosystems: a review. Mitig Adapt Strateg Glob Chang 11:403-427

Madan RN, Roymoulik SK (1990) Evaluation of Grevillea robusta as a raw material for the production of dissolving pulp and viscose rayon. Indian J Fibre Text Res 15:180-184

Miftah F, Tsegaye B, Sisay F (2017) Impact of energy consumption on indoor pollution in rural wooden houses of Southern Ethiopia in times of climate change. Glob J Curr Res 4(3):14-26. ISSN: $2320-2920$

Namaalwa J, Sankhayan PL, Hofstad O (2007) A dynamic bio-economic model for analyzing deforestation and degradation: an application to woodlands in Uganda. Forest Policy Econ 9:479-495

Oduor NM, Githiomi JK (2013) Fuel-wood energy properties of Prosopis juliflora and Prosopis pallida grown in Baringo District, Kenya. Afr J Agric Res 8(21):2476-2481. https://doi.org/10. 5897/AJAR08.221. http://www.academicjournals.org/AJAR

Okoroigwe EC, Zhenglong LI, Shantanu K et al (2015) Bio-oil yield potential of some tropical wody biomass. J Energy South Afr 26(2):33-41

Roberts KG, Glory BA, Joseph S et al (2010) Life Cycle Assessment of bio-char systems: Estimating the energetic, economic and climate change potential. Environ Sci Technol 44:827-833

Shackley S et al (2012) Biochar, tool for climate change mitigation and soil management. In: Meyers RA (ed) Encyclopedia of sustainability science and technology. Springer, New York

Sheng C, Azevedo JLT (2005) Estimating the higher heating value of biomass fuels from basic analysis data. Biomass Bioenergy 28(5):499-507. https://doi.org/10.1016/j.biombioe.2004.11.008

Shimelis B (2011) Generation, composition and characteristics of urban solid waste in a major Khat producing and marketing area in Eastern Ethiopia. Int J Environ Prot I(5):9-16. Retrieved from http://www.ij-ep.org

Xiu S, Shahbazi A (2012) Bio-oil production and upgrading research: a review. Renew Sust Energ Rev 16:4406-4414. https://doi.org/10.1016/j.rser.2012.04.028

Yishak AY (2014) Liquid fuel production through pyrolysis of Khat and plastic waste mixture. A Thesis Submitted in Partial Fulfillment of the Requirements for Master Degree in Chemical Engineering under Env Engi Addis Ababa Institute of Technology (AAiT), School of Chemical and Bio-Engineering

Open Access This chapter is licensed under the terms of the Creative Commons Attribution 4.0 International License (http://creativecommons.org/licenses/by/4.0/), which permits use, sharing, adaptation, distribution and reproduction in any medium or format, as long as you give appropriate credit to the original author(s) and the source, provide a link to the Creative Commons license and indicate if changes were made.

The images or other third party material in this chapter are included in the chapter's Creative Commons license, unless indicated otherwise in a credit line to the material. If material is not included in the chapter's Creative Commons license and your intended use is not permitted by statutory regulation or exceeds the permitted use, you will need to obtain permission directly from the copyright holder. 